\title{
Regulating the Stage: Storms, Wrecks and Lifebelts in the Italian Experience
}

\author{
By Francesca Sabatini* \& Michele Trimarchi ${ }^{*}$
}

The paper analyses how the performing arts are structured and regulated in Italy. The orientation and the trend of the legislation shows an endemic instability due to the prevailing view of permanent emergency generated by a combination of static subsidies and peer evaluations. The ambiguous equilibrium between centralization and delegation on a National and Regional level, as well as the byzantine categorisation of the different administrative structures, ended up generating a slow and inefficient managerial system, on the one hand, and the uncertainty and mistiming of funds, on the other hand. Moreover, the amount of funds devoted to supporting the performing arts organisations has been progressively reduced, while the contradictory mechanisms aimed at establishing their distribution has been strengthened, providing theatres and companies with a clear incentive to overemployment, conservative choices, and managerial rigidity. The analysis of the Italian legislation aimed at supporting the performing art system shows a sequence of many acts clearly generated by financial emergency. Each new act has been aimed at counterbalancing the fragilities generated by the previous act, and has paradoxically generated new emergencies, in a sort of self-weakening sequence whose dominating value has constantly been the search for survival.

Keywords: Italy, Arts, Institutions, State, Reform, Regulation.

\section{Introduction}

A substantial reform is needed, in order for the institutional framework, the legal and organisational structure, the fundraising actions and the network of external synergies to be restructured. Internal flexibility, external versatility, serious monitoring and sanctions for managerial choices should be firmly introduced, also in absence of any rises in the amount of public funds. Also the inter-jurisdictional relationships need some radical changes inverting the longlasting view based upon an inverted subsidiarity. These issues are discussed in four sections of this paper.

The first section of the paper introduces the institutional framework for the performing arts at a macro (i.e., National, Regional, Local level): in particular, an overview of the legislation regulating the performing arts, with reference to the reforms pertaining to the Ministry of Culture and to the coordination (or, better, absence of coordination) between the Ministry and Regional authorities.

The second section introduces the micro (organisational) level: primarily, the categorisation with which the Italian law identifies different forms of performing arts organizations, and deals with each individually; secondarily, the strong

${ }^{*}$ Doctoral Student, University of Reggio Calabria Mediterranea, Italy.

†Professor of Public Economics, University of Catanzaro Magna Graecia, Italy. 
structural reforms which have affected theatres, and especially the practice of controlled organisation and the recovery plans introduced with Law n.112/2013.

The third section is dedicated to the funding system for the performing arts, and presents an overview of its breakdown between the various performing arts, of the Council evaluating candidates to the fund, of the allocation criteria; the incentive to private donations, which became effective for theatres only in 2017, is also analysed in the section.

A fourth section draws conclusions from the institutional framework outlined above: the uncertainty generated by the ambiguous legislation concerning the dualism of State and Region in regulating the sector, the decades-long state of emergency of the performing arts and the constant but unprofitable efforts of the State to reform call for more effective tools and actions: decentralisation should aim at diversifying tasks at the different administrative levels, rather than juxtapose them. The obsolete and rigid grid of the funding system requires a restructuring of the allocation criteria which should not just consider quantitative indicators, but also valorise social action, inclusion and engagement on behalf of the performing arts organisations, and strongly consider the impact of their action upon their territorial community.

\section{Art and the State: The State of the Art}

\section{Reforming Reforms: A Legislative Roulette for Culture}

With the Ministerial Decree of 12 July 2018 the former Ministero dei Beni e delle Attività Culturali e del Turismo, the Italian Ministry of Culture, was subject to a reform aimed at reorganising its functions. Tourism in particular, initially pertaining to this Ministry, was delegated to the Ministry of Agricultural, Environmental and Forestry Policies. The Ministry is now renamed Ministero dei Beni e delle Attività Culturali.

Of the reforms which the dramatic state of the Italian cultural sector calls for, the one of 2018 was definitely not the most needed; what is more, it is but the last of a decades-long series of administrative revisions: the Ministry of Tourism and Performing Arts, born in 1959, was first reformed in 1974 and then abrogated in 1993, in order to be re-founded in 1998 with the name it has today, i.e., after the reform of 2018; more reorganisations of the State administration of culture occurred again in 2006, 2007, 2014.

Moreover, matters such as tourism were subject to restless reassignments from one Ministry to the other - it was only recently, in fact, and precisely in October 2013, that the Ministry of Culture had been assigned jurisdiction over tourism by the former Government. Tourism, after all, was not the only delegation to be rebounded back and forth: at the time of its creation in 1998, sports pertained to the Ministry of Culture, but was assigned to the new-born Ministry for Youth Policies in 2006.

The abundant, if not redundant, modifications to the State apparatus of culture coincided with a nominal, more than a factual reorganisation, as is evident not just 
at the ministerial level, but also from its subordinate Directorate General of the Performing Arts, which is the specific focus of the present paper. The performing arts in fact, more than any other subsector of the Ministry, were subject to severe legislative impositions over the past twenty years, which contributed to, rather than relieved, the crisis of the sector.

Political discretion and the sequential governments of different orientations can be pointed out as one cause of the unstable legislation regulating the performing arts; the wave of reforms fostered by the rise of New Public Management (NPM) in the 1990s caused Italy to rethink the structure and management of theatres among other sectors of the public administration - which, filtered by the more or less acute sensibility of the Italian legislators, resulted in controversial choices, such as the transformation of opera theatres from public entities into hybrid public-private Foundations. Moreover, the total absence of a long-term vision and of sustainability makes the legislation resemble an uneven patchwork more than a rational path towards effectiveness.

Among the consequences is the persistent uncertainty of a regulation which is refuted with appalling frequency by subsequent amendments and procedures of abrogation: this causes the persistence of unresolved problems of a sector which was never effectively restructured, though constantly deconstructed.

In the second place, the accumulation of Laws and Ministerial Decrees over the years generated an articulated taxonomy of cultural actors, a long set of definitions and boundaries whose obsolescent rigidity does not account for the natural fluidity of the performing arts scenario. This results in a discrepancy between policies and their object, i.e., artists, companies, theatres and the like, and generates a slow bureaucratic engine.

In the third place, the rapid turnover of actions addressed to culture and, more specifically, to the performing arts generated confusion and bureaucratic dispersion of criteria, definitions, institutional bodies; this confusion hinders access to information from the part of performing arts organisations, and favours the reiteration of public support to a few, established institutions.

\section{Culture \& Culture, Inc.: The Ministry and Its Tautological Branches}

The formidable grid of legal impositions makes dependence on National centralised bodies inevitable for the performing arts organisations from a variety of perspectives: from the hiring of personnel, which happens through National agencies and formal (rectius, endless) procedures of approval, to financial aid, which criss-crosses Regional support tools, to the management of the institutions themselves, whose expenses, content production, and direct management the Ministry scrupulously scrutinizes not just through Ministerial branches, but also through the practice of commissariamento, with which theatres' state of emergency is handled through special governmental commissioners who divest the theatre's board of directors. This procedure will be dealt with in detail in the second section of the paper.

The decentralisation system developed by the Ministry of Culture resembles, in facts, a decentralised centralisation: agencies and companies entirely managed 
by the Ministry were founded with the supposed aim of simplifying procedures; the outcome, in reality, was a ministerial doppelganger which increased the Ministry's bureaucratic control over the performing arts organisations. The first of such companies, Ales S.P.A., was founded in 1997 and incorporated to another Ministry-owned company, Arcus (born in 2004), with the Stability Law of 2016.

The Ministry is the only member of both companies' board; the purpose of each does not differ consistently from one another, nor from that of the Ministry itself, i.e., to identify and support relevant cultural projects with technical and financial resources. The overlap between the three is almost total, but the bureaucratic efforts are tripled, and so is the inference of the State over every aspect of cultural projects.

The Ministry is additionally articulated into Directorate Generals for each cultural field which, in their turn, are supported by advisory boards. In the case of the Directorate General of the Performing Arts, not differently from the Ministry itself, it is the result of the merging of different Institutes, namely ETI (Ente Teatrale Italiano) and EIST (Ente Italiano per gli Scambi Teatrali). In present days, it is broken down into a Consulta and different consulting bodies, each for every type of performing art identified by State taxonomy: dance, theatre, music and opera, circus, and, since 2018, historical carnivals.

\section{Anatomy of (in)dependence: The Regional System from Segmentation to Duplication}

When, in 2004, Tuscany appealed to the Constitutional Court claiming full authority over the performing arts in the Region, the Court, with sentences n.255/256, rejected the appeal and declared the performing arts a matter of concurrent legislative power between State and Regions.

Leaving temporarily aside any value judgement concerning the coordination of power between the State and its constitutive elements, i.e., Regions, the (not-so) hidden truth behind this matter is the absence of clear indications, in the Italian Constitution and even in its following amendments, regarding such coordination. The result is, rather obviously, the absence of coordination between State and Regions, and stresses once more the ineffectiveness of reforms for the performing arts in Italy.

Article 117.2 of the Italian constitution disciplines legislative power of State and Region. When the article was reformed through Constitutional Law n.3/2001 ${ }^{1}$, "the valorisation of cultural and environmental goods and the promotion and organisation of cultural activities" were listed as subject to concurrent power of both State and Region; all items not falling under this category (or under the category of special legislative power, exercised by the State) were subject to the general power of Regions.

As if the highly hierarchical anatomy of the Ministry had not generated enough confusion with gears of interdependences and chains of delegations at the macro-level, the absence of clear directives concerning regions and the performing arts in the Constitutional Law of 2001 generated further confusion at the Regional

${ }^{1}$ For the sake of philological appropriateness, the authors have chosen to adopt an Italian nomenclature for laws and decrees. 
level and gave rise to different interpretations among jurists and Regional authorities (Brigato 2008); the sentence against Tuscany, besides filing the case, did not provide Regions with any specific indication on the actual nature of this concurrent power.

Regional specificity in Italy is the historical result of scattered conquests, cultural mélanges, and unpredictable contaminations. Regions organised their legislation for the performing arts in a diversified way: some have legislated so as to support culture in a holistic and strategic way, focusing on social impact (Lazio, Regional Law n.15/2014), on the programming of integrated and multidisciplinary projects (Lombardy, R.L. n.25/2016, Basilicata, R.L. n.37/2014), on regional networks of performing arts (Marche, R.L. n.11/2009), while others focused on promotion only (Umbria, R.L. n.17/2004, Campania, R.L. n.6/2007). Most regional laws also mention local specificities of language and of cultural expression as relevant forms of heritage.

Of all the policy tools for culture in Italy, the Regional ones potentially place themselves more than any other as a vital junction between the National and the local level; nonetheless, these well-drawn declarations of intents produced, in most cases, a mere duplication of State legislation on the performing arts at a regional level (Trimarchi 2015). An indolent administrative escamotage which ended up generating public calls erga omnes, with rigid criteria and a closer attention to the organisational structure than to creativity; this ends up favouring the same institutions already supported by the State - or vice versa: the Ministerial Decree of 27/07/2017 (M.D. hereon) mentions the obtaining of Regional Funds as a criterion for obtaining State funds: a juxtaposition of resources and tools favouring organisations which, being established, are more easily evaluated, supposedly more solid, and often sustained by discretional political relationships.

\section{Mirrors and Mirages: The Unachieved Experiment of Regional Observatories}

Attempts to rationalise the Regional role in the support of the arts were made; in 2004 a conference was held in Bologna, called "Regions and the performing arts: Regional proposals for a National Law in the framework of constitutional reforms",2.

In 2007 the Ministry of Culture, and organisations representing Provinces (UPI) and Municipalities (ANCI) subscribed a document for the performing arts activities (Patto per le attività culturali di spettacolo) that aimed at creating synergy among the different levels of administration in managing the performing arts.

A project was crafted after this meeting, ORMA, that would lead to the creation of Regional Observatories for the performing arts all over the peninsula, fostering a more holistic view of culture while promoting interregional cooperation and State-Region cooperation (Taormina et al. 2011). Vital nodes in the project were the National Observatory (funded with Law 163/1985), the Piedmont Observatory and that of Emilia Romagna.

${ }^{2}$ Le regioni e lo spettacolo. Le proposte delle regioni per una legge nazionale di principi nel quadro delle riforme costituzionali. 
Rather than estimating differences and drawing hierarchies between incomparable regional situations, ORMA aimed at providing Regional administrations with shared knowledge on best practices and ideal performance indicators. However virtuous, it had to come to terms with the limits of a lagging system and of a heterogeneous regional patchwork. Observatories, be them for culture or for the performing arts, are still missing in most regions and Regional authorities fail to serve as a focal junction between performing arts organisations operating within a specific territory and National support tools.

The observations that the existing observatories produce are often of little relevance to the purpose of actively interpreting the signs and patterns of culture in Italy: instead of understanding how creativity is spread across the peninsula, numerical data is provided on the Regions whose institutions earn the larger amounts of funds - an almost obvious statement of development inequalities on the Italian territory. Instead of focusing on the type of projects for which organisations apply (be them multidisciplinary, educational and so on), the reports produced by the National Observatory names the organisations which have earned the maximum or the minimum amount of the Fund ${ }^{3}$.

\section{A Theatre is a Theatre is a Theatre: In the Trap of Labels}

\section{A Painting with Too Many Frames}

Differently from nearly every other aspect of the Italian law, very little literature is available on the evolution of the legal framework of the performing arts. While it has seldom captured the attention of jurists and researchers, making sense of the overabundant legislation on the performing arts in Italy also goes beyond the possibilities of its main target - the performing arts themselves. The self-referential, insistent reformative effort of the Ministry produced, up to the present day, an endless number of laws, ministerial decrees, decree-laws through which the performing arts field has been chained, more than regulated.

Such legislation is as full of aborted attempts of reforms as it is of achieved reforms: draft framework laws, in the past twenty years only, were presented and subsequently abandoned in 2001 (MP Carlucci), in 2004 and 2005 (MP Rostani), in 2006 (MP Luxuria), in 2007 (M Ciocchetti), in 2008 (MPs Carlucci and Barbareschi), 2013 (MP Rampi). The approved reforms were probably as many as, if not more than, the unachieved ones, a symptomatic evidence of legislative overabundance.

The full story of the Italian legislation over the performing arts can be articulated into three couplets of contradictory directives. A vast, supposedly allencompassing nomenclature was established in order to comprise all the performing arts activities the State could identify.

According to the M.D. of 27/07/2017, each performing arts category (music and opera, theatre, dance, circus) is structured in different forms of institutional

${ }^{3}$ This information is extracted from the Report of the National Observatory on the use of FUS for the year 2016 . 
structures: regional networks (circuiti), companies (imprese), entities (organismi), centres (centri). The actions of such institutions are in their turn broken down into production, planning, purchases (which applies to circuses and travelling shows), and transversal actions. Each sector is then additionally categorised according to its specificity: in the case of prose theatres, for instance, the Decree makes a distinction between National Theatres, Theatres of relevant cultural interest, Theatre production companies, Theatre production centres, and Festivals. The difference between categories is assessed according to the volume of production and the number of regular employees, but variations are slight, and some theatres are sometimes forced to publish tenders and hire employers temporarily in order to remain in their privileged category.

There is almost no need to comment any further the misty superabundance of the Ministerial categories, especially considering that the nomenclature is so excessively punctilious, that definitions often overlap, and some theatres fall under more than one category; what is more, in most cases not only categories, but even criteria for fund eligibility overlap, focusing on the number of workdays, on the maximum number of co-productions, on the number of performances.

A first indirect consequence of the rigid identification of subjects and institutions is that, more than fostering actual diversification of the cultural offer and promoting young creativity through effective performance indicators, the Ministerial Decree ends up favouring those institutions that are already established and have a more structured organisation, because they fulfil institutional requirements.

The second one is the accumulation of sometimes contradictory criteria: Law $175 / 2017$ indicates networking through co-productions as one of the necessary requirements to access funds, while M.D. 27/07/2017 sets for every organisational category a ceiling for the number of co-productions; in the evaluation criteria for the eligibility to the Italian National Fund for the performing arts (FUS hereon), established by M.D. of 03/02/2014, points are halved when taking into account educational activities, while Law 175/2017 establishes that at least 3\% of FUS will be dedicated to those same educational activities.

\section{A Revolution with Too Many Barricades}

An effort was made, especially in recent years, to homogenise a legal structure which had operated hoppling from decree to decree on a yearly base: before the M.D. of $03 / 02 / 2014$, for instance, criteria for eligibility to public funding of the Lyric-symphonic Foundations (the main Italian opera theatres, LSF hereon) were set annually.

Similarly (and yet differently, since the LSF are, rather controversially, subject to a different set of laws), the criteria for the other performing arts activities were determined by ad hoc decrees: Theatre was regulated by the M.D. of 12/11/2007, Dance by M.D. of 08/11/2007 and so forth. M.D. of 01/07/2014 is the first decree aspiring to regulate the performing arts as a whole - besides, again, opera theatres. 
Nonetheless, even the M.D. which claimed to bring stability were eventually abrogated and supplanted by other, more recent decrees: M.D. 03/03/2017 announced the attribution of extra funds to the LSF, establishing new eligibility requirements which ran parallel to the ones of 2014. A multiplication of deadlines and objectives which most opera theatres are gasping to reach due to their still unresolved difficulties. M.D. 27/07/2017 substitutes the one of 2014 in setting the criteria of public support to the rest of the performing arts. No relevant difference between the two decrees can be pointed out, with the only consequence of causing instability and adding growing confusion to the legal scenario. The M.D. of 2014 itself, after all, did not homogenise the scattered former decrees under a coherent legal rationale, but rather patched them all together in a redundant document.

Law 175/2017, the most recent provision concerning the intricate legal framework of the performing arts, goes even further in mining its own effectiveness, since it anticipates the draft of a more structured and definitive law, a framework-law named the Performing Arts Charter (Carta dello spettacolo). The deadline for the promulgation of the Charter was set on the 31 of December 2018, but the political twist of the elections in march 2018 postponed the priorities of the cultural agenda: the "silent shipwreck" of the Charter is now complete".

\section{A Highway with Too Many Side-Streets}

The wave of reforms fostered by the spread of New Public Management (NPM) in the 1990s had a lasting effect on the Italian administration of culture, though assimilated in a specific fashion attributable to the legal structure of Italy among other Rechtstaat Countries (Bonini Baraldi 2014).

Among the urgencies brought up by the NPM discourse was the increase in efficiency and the blurring of boundaries between public and private sectors. In the case of the performing arts in Italy, these instances were put into practice with a structural reform whose results ended up being more nominal than factual; namely, it consisted of the transformation of many performing arts institutions from public entities to Foundations subject to private law.

The change happened in 1996, when Law 367 marked the beginning of an "era of Foundations": the LSF came first, which turned the 13 main Italian opera theatres into Foundations; the Venice Biennale followed, to which Law-Decree of 20/01/98 n.19 gave the features of a private company, together with the National Institute for Ancient Drama, INDA, transformed into Foundation with the LawDecree of 29/01/98 n.20. Foundations would feature the inclusion of private members within a more equilibrated board of directors, a more transparent election of the Superintendent, a more efficient use of resources according to specific budget constraints.

The auspicated stream-lining of bureaucracy, legislative homogeneity, managerial autonomy and effectiveness were never reached. Again, new subcategories were formed: Law 106/2014 decreed the birth of Special Foundations; Accademia di Santa Cecilia and Teatro alla Scala were declared

\footnotetext{
${ }^{4}$ Il silenzioso naufragio del codice dello spettacolo, A teatro webzine, 30th December 2018.
} 
Special Foundations in 2015, and due to their "renowned artistic excellence" ("comprovata qualità artistica" in the Italian text) are granted yearly a fixed amount of FUS.

This aspect of the legal framework triggers a particularism without specificity based on discretional hierarchies, which favours exclusively the excellence rather than providing support to the lagging Foundations or to those with specific features.

In addition Law 175/2017, merely a declaration of intents on the part of the State, did not only anticipate the still unwritten Carta dello spettacolo; it also anticipates that Foundations will be downgraded to Lyric-Symphonic Theatres, losing a consistent portion of public support, if they do not reach structural balance within 2019.

The structure of opera theatres would be altered once more; this leads to two possible conclusions: that here was an initial misjudgement in setting deadlines for reaching structural balance on behalf of the LSF - especially considering that, since 2013, when the deadline was set to 2016, this doomed zero-hour was postponed to 2018 with budget Law 208/2015, and then again with Law 175/2017; it could alternatively be concluded that the step backwards bears witness to the failure of a managerial system, the one brought up by Law 367/1996, which did not improve public management of opera theatres as expected.

This is additionally demonstrated by the strong inference of the State in the non-existent autonomy of Foundations. The reform in facts, with its ever-changing nomenclature of opera theatres (ente pubblico, Fondazione, Fondazione speciale, Teatro lirico-sinfonico) and the mistimed deadlines, added further confusion and laid the foundations for further amendments and procrastinations.

Still, the most controversial and relevant aspect of the reform lies elsewhere, and particularly in the fact that the nature of theatres as public entities was never really reformed.

First, interpretative controversies due to the obscurity of the law arose about the public-private hybridisation happened in LSF: in 2011 the Constitutional Court emanated the sentence n.153 with which it specified that the core of the Foundations' structure was still public: Foundations were not, after all, so different from what they were before - public entities.

Second, public enforcement has deprived the reform of its meaning over and over ever since Foundations began operating. In many occasions and through different tools the Ministry has intervened directly on the management of Foundations: far from improving the persistent state of crisis of opera theatres, Foundations were in such a critical state that the Ministry sent special commissioners with the power of divesting the Board of Directors and controlling Foundations directly. INDA was subject to this practice (commissariamento) in 2016, while 9 out of the 13 LSF were put under this Ministerial administration in the time span 2008-2012.

It has been pointed out how the lack of transparency in the designation of the commissioners and their absolute power over Foundations echoes political relationships that are somewhat feudal in their discretion (Ferri 2012). 
Commissariamento represented the peak of Ministerial inference in the autonomy of Foundations - but not its ending. The still critical weaknesses of the Foundations' management, and especially of LSF's, led to the promulgation of law 112/2013: recovery plans were to be submitted by the Foundations' boards and to be evaluated by an external governmental commissioner in order for Foundations to be eligible to a rotation fund. Whereas the inference of the State was not as strong as it used to be with commissariamento, it represented, together with the downgrading anticipated by Law 175/2017, the ultimate failure of an incomplete reform.

\section{Funds and Refunds: The Deficit-Covering Counterstrategy of the Italian State}

When public support to the performing arts in Italy was first formalised, with the Decree-Law 438 of 03/02/1936, the State was declared responsible for covering the possible deficits of the sector (eventuali disavanzi, in the Italian text). Though much has changed in almost a century of public support to the arts, FUS allocated according to often obsolete and discretional criteria aimed at ensuring the mere survival of the sector, dramatically reduced year after year, is still interpreted as a deficit-covering measure rather than an investment on the performing arts culture.

The persistent state of emergency of the sector in facts prove how the lack of any strategic planning on behalf of the Directorate General, combined to an inefficient management of resources on behalf of unprepared administrations, are the core structural weakness of the funding system.

Besides the lack of consistency between the Ministerial and the organisational level, problems in the funding systems can be highlighted at different levels: confusion at the bureaucratic level, constant reductions, mistiming, particularism, if not political discretion, in the allocation of extra funds, obsolete criteria of evaluation.

Like many of the institutional bodies which have been previously analysed (the Ministry, the rigidly categorised theatres, Foundations), the Council evaluating candidates to FUS was subject to numerous nominal modifications which changed the composition of the Council itself, without really implying a significant change in the allocation criteria or on the effectiveness of this tool.

The first Council, Consiglio Nazionale per lo Spettacolo, was established with the creation of FUS (Law 163/1985); it was abrogated with Law 650/1996, which assigned the tasks previously performed by the Council to the new-born Committee for the issues of the performing arts (Comitato per $i$ problemi dello spettacolo). A Decree of the President of the Italian Republic (D.P.R. 89/2007) introduces, barely 10 years later the formation of a new consulting body, the Council for the performing arts (Consulta per lo spettacolo), thus abrogating the precedent Committee. The most recent modification to the structure of consulting bodies dates to 8 November 2017, as introduced by Law 175/2017: a fourth council is created, the Consiglio superiore dello spettacolo, which substitutes the 
previous Consulta with the announced aim of providing the ministry with consultancy services and support in the design of the strategies for the performing arts.

Since its foundation, more than thirty years ago, the Fund was subject to significant reductions attributable to cuts in public spending for culture, to the economic crisis, to changes in monetary values. From 1985 to 2016, FUS has been reduced by $54 \%$, while the ratio of FUS and GDP decreased by over $71 \%$, indicating a disquieting fall in public spending on culture.

The rotation fund established with Law 112/2013 came to rescue the LSF with 74 extra million Euros, increased by 10 million Euros with Budget Law 205/2015; in the meantime Law 175/2017 increased FUS by 10 million for both 2018 and 2019, anticipating an increase by 20 million euros starting from 2020; even so, as said before, no substantial change in the managerial mindset of theatres really occurred in spite of the administrative transformations these institutions were subject to: the inefficient management of resources was perpetuated.

Extemporaneous increases in funds, which are not part of a comprehensive strategy nor related to a scope any wider than mere, temporary rescue, are added to the overall FUS almost from one month to the other; it must be considered that this uncertainty in timing is embedded in an even more uncertain framework - that of a yearly-attributed fund, and not, as it was initially established by Law 600/1985, of a three-years funding plan which would better suit the ordinary long-term vision in theatres' planning of their seasons.

The mistiming in the allocation of resources is not just symptomatic of an idiosyncrasy between policymakers and the funded institutions; in some cases it also hides discretional political adjustments: the M.D. of 28/05/2018, n.229, allocates 1.330.505 million Euros to, respectively, La Scala and Opera di Roma in reason of their "special needs" (maggiori esigenze). This mention either evokes an initial misjudgement about the resources needed, or, more likely, a non-objective choice quite weakly justified in the light of a sudden reconsideration of the two theatres' needs.

Such particularism without specificity in funding has already been pointed out in 2.3: whereas La Scala and Accademia di Santa Cecilia are granted a regular amount of the Fund, other theatres with specific features do not find congruous recognition of their necessities in scoring points for FUS: waging the cost of their own ballet company, for instance, is not accounted for while evaluating a theatre. Similarly, the M.D. of 27/07/2017 establishes minimum percentages to be compulsorily attributed to certain institutions, namely the Venice Biennale and INDA (minimum 1\%) and Il Piccolo Teatro (6.5\%).

The absence of evaluative considerations in the cases described above is indicative of the overall trend of public support to the performing arts in Italy, a support which is oriented towards subjects, rather than towards projects (Balestra and Malaguti 2000), a stress is put on the institution itself and on its past performance, usually evaluated according to a combination of numerical indicators (number of actors on the stage, of musicians in the orchestra and the like) and of qualitative aspects. The latter aspect is particularly sensitive: the evaluation of artistic quality in the performing arts is strictly linked to, again, the past 
performance of a theatre - assuming, as in an enthymeme, that past quality acts as a grant for the future.

Moreover, it has been pointed out how the ability of the cultural offer to form the audience's critical sense is tied to its pluralism and its variety, not at all to a few initiatives which experts believe to be excellent (Trimarchi 2015). Thus, not only is this peer evaluation not objective and not relevant for assessing value in the performing arts, it is often neglectful of the target and purpose of the arts themselves, such as the emergence of creativity and the social impact of audience involvement.

It is relevant, in this respect, to mention a paradoxical and contradictory examples: free performances held by theatres in disadvantaged neighbour-hoods, such as the initiatives of Opera di Roma and Teatro Massimo di Palermo, are not acknowledged by FUS evaluation criteria because they do not generate revenues: State support is missing precisely for those activities which, not being profitable, need that support in order to generate value for the citizens.

\section{So we beat on, Boats against the Current...}

The many storms that the ship of State regulation of the performing arts has gone through have led to just as many shipwrecks. In spite of an abundant legislation, the Italian system never managed to prioritise issues and to ensure a sustainable development for the sector, intended as avoidance of short-term or temporary solutions that do not address fundamental issues (Throsby 2015). As the previous sections of the paper have tried to point out, three main problems affect the performing arts transversally.

First, the constant Ministerial twists, more nominal than factual; the absence of coordination between State and Regions, i.e., between national and local levels of management; the rise and fall of the many FUS Councils; the excessive categorisation of performing arts structures and institutions, which focuses on formal achievements while driving the attention far from projects and their impact; the shift towards private-like Foundations, not supported by a real shift in management and still characterised by the weaknesses of the preceding institutional structure; all this factors generated a perpetual chain of deconstruction and rearrangements which never effectively reformed the sector, but rather threw it into turmoil.

Second, the promulgation of new laws, which happens at a frantic rhythm (on a yearly basis or more), patches a scratched blanket without fixing its holes, causing uttermost instability in a legal system characterised by laws which are not destined to last: the procrastinating attitude of Law 175/2017 and the suppression of M.D. 21/07/2014 by M.D. 27/07/2017 are but the most recent examples of a recurring pattern.

Political discretion and particularism, finally, seem to drive choices within the evaluation grid for the allocation of funds; qualitative indicators established by peer juries rule over the emergence of new forms of creative processes; tenders address the performing arts in its entirety, from emerging organisations to 
established institutions: in such a framework, though with a certain degree of diversification, criteria and boards of evaluation are not able to adopt the flexibility that is needed face to the vastness of the creative scenario. What is more, very little attention is paid not just to artistic creativity, but to involvement processes and to education.

The crisis of the performing arts in Italy calls for something more than the umpteenth reform: new tools and actions should be put into practice in order to regulate and regularise the legal dispersion of the framework while simplifying the suffocating accumulation of definitions and categories.

The coordination between State and Regions should not be articulated as a juxtaposition of overlapping laws and structures, but rather as a mediating tool between the national/international level and the local one: State support should be centred on supporting the performing arts as a whole, in both their traditional and experimental forms, while Regions should act as vital node for the maximum diffusion and promotion of the arts at the local level, avoiding centralizations; at the provincial and municipal level, administrations should valorise theatrical infrastructure and tie them to the urban itineraries of citizens.

A long-awaited framework-law should finally provide organic guidelines for the effective management of performing arts institutions, while clarifying the role of the State in their support. For what concerns the latter point, it is easy to notice how State support merely serves as fund allocator, according to subjective and, it could be said, volatile criteria of evaluation. The actual support of the State should not just be financial, but substantial, through opportunities for sharing best practices and access to formation, in order for administrations to reach the intended autonomy and for the use of resources to be not just efficient, but effective.

In order to establish criteria that better suit both the demand and the offer for culture, observatories should emerge from their hibernation and draw a more holistic map not just of the performing arts, but of culture: a more active use of audience data and of the information collected could help understand individual motivations in the search for cultural goods, and be of vital help to policymakers in designing more effective tools for public action towards the arts.

\section{Bibliography}

Balestra C, Malaguti A (2000) Organizzare Musica: Legislazione, Produzione, Distribuzione, Gestione nel Sistema Italiano. Milan: Franco Angeli.

Bellocci M, Passaglia P (2009) La giurisprudenza costituzionale relativa al riparto di competenze fra Stato e Regioni in materia di ambiente e di beni culturali.

Bonini Baraldi S (2014) Evaluating results of public sector reforms in Rechtsstaat Countries: the role of context and processes in the reform of the Italian and French cultural heritage system. International Public Management Journal 17(3): 411-432.

Brigato L (2008) Strumenti Legislativi Comparati Sullo Spettacolo Dal Vivo. MIBAC Osservatorio dello Spettacolo.

Ferri P (2012) L'eccezione è La Regola: Ricerca Esplorativa sul Fenomeno del Commissariamento nel Settore Culturale Italiano. Alma Mater Studiorum Università di Bologna. 
Taormina A et al. (2011) Osservare la Cultura. Nascita, Ruolo e Prospettive Degli Osservatori Culturali in Italia. Franco Angeli.

Trimarchi M (1993) Economia e Cultura. Organizzazione e Finanziamento delle Istituzioni Culturali. Franco Angeli.

Trimarchi M (2015) Il Sostegno Regionale dello Spettacolo: Ruolo, Strumenti e Strategie, Treccani.

Throsby D (1995) Culture, Economics and Sustainability, Journal of Cultural Economics, 19.

\section{Legal Sources}

L. 617/1959 Istituzione del Ministero del turismo e dello spettacolo.

Legge 800/1967, Nuovo ordinamento degli enti lirici e delle attività musicali

Legge 657/1974, Istituzione del Ministero per i beni culturali e ambientali

Legge 163/1985, Nuova disciplina degli interventi dello Stato a favore dello spettacolo

L. 367/1996, Disposizioni per la trasformazione degli enti che operano nel settore musicale in fondazioni di diritto privato.

L. 59/1997, Delega al Governo per il conferimento di funzioni e compiti alle regioni ed enti locali per la riforma della Pubblica Amministrazione e la semplificazione amministrativa.

D.Lgs. 112/1998, Conferimento di funzioni e compiti amministrativi dello Stato alle regioni ed agli enti locali, in attuazione del capo I della legge 15 marzo 1997, n. 59.

Legge 368/1998 Istituzione del Ministero per i beni e le attività culturali

D.L. 345/2000, Disposizioni urgenti in tema di Fondazioni lirico-sinfoniche

D.Lgs. 2812004, Riforma della disciplina in materia di attività cinematografiche, a norma dell'articolo 16 della L. 6 Luglio 2002 n.137

L. 128/2004, Conversione in legge, con modificazioni, del decreto-legge 22 marzo 2004, n. 72 , recante interventi per contrastare la diffusione telematica abusiva di materiale audiovisivo, nonché a sostegno delle attività cinematografiche e dello spettacolo.

D.L. 18/06/2006, n.181 Disposizioni urgenti in materia di riordino delle attribuzioni della Presidenza del Consiglio dei Ministri e dei Ministeri.

D.P.R 14/05/2007 n.89, Regolamento per il riordino degli organismi operanti presso il Ministero per i beni e le attività culturali, a norma dell'articolo 29 del decreto-legge 4 luglio 2006, n. 223, convertito, con modificazioni, dalla legge 4 agosto 2006, n. 248.

D.M. 29/10/2007, Criteri generali e percentuali di ripartizione quote Fondo unico per lo spettacolo, di cui alla legge 30 aprile 1985, n. 163, destinata alle fondazioni liricosinfoniche.

D.P.R 26/11/2007 n.233, Regolamento di riorganizzazione del Ministero dei beni e delle attività culturali, a norma dell'articolo 1, comma 404, della Legge 27/12/2006, n.296.

L. 244/2007, Disposizioni per la formazione del bilancio annuale e pluriennale dello Stato (legge finanziaria 2008). ${ }^{5}$

L. 100/2010, Disposizioni urgenti in materia di spettacolo e attività culturali.

L. 112/2013, Disposizioni urgenti per la tutela, la valorizzazione e il rilancio dei beni e delle attivita' culturali e del turismo.

L. 106/2014, Disposizioni urgenti per la tutela del patrimonio culturale, lo sviluppo della cultura e il rilancio del turismo.

D.M. 03/02/2014 Criteri generali e percentuali di ripartizione della quota del Fondo Unico per lo Spettacolo, destinata alle Fondazioni lirico - sinfoniche.

\footnotetext{
${ }^{5}$ Credito d'imposta al cinema.
} 
D.M. 01/07/2014, Nuovi criteri per l'erogazione e modalità per la liquidazione e l'anticipazione di contributi allo spettacolo dal vivo, a valere sul Fondo unico per lo spettacolo, di cui alla legge 30 aprile 1985, n. 163.

D.P.C.M. 29/08/2014, Regolamento di organizzazione del Ministero dei beni e delle attivita' culturali e del turismo, degli uffici della diretta collaborazione del Ministro e dell'Organismo indipendente di valutazione della performance, a norma dell'articolo 16, comma 4, del decreto-legge 24 aprile 2014, n. 66, convertito, con modificazioni, dalla legge 23 giugno 2014, n. 89.

D.L. 50/2017, Disposizioni urgenti in materia finanziaria, iniziative a favore degli enti territoriali, ulteriori interventi per le zone colpite da eventi sismici e misure per lo sviluppo. ${ }^{6}$

D.L. 91/2017, Disposizioni urgenti per la crescita economica del Mezzogiorno ${ }^{7}$.

D.M. 03/03/2017 n.105 (ripartizione milioni extra FUS)

D.M. 27/07/2017 Criteri e modalità per l'erogazione, l'anticipazione e la liquidazione dei contributi allo spettacolo dal vivo, a valere sul Fondo unico per lo spettacolo di cui alla legge 30 aprile 1985, n. 163.

D.M. 28/02/2018 n.129, Decreto di riparto Fondo Unico per lo Spettacolo - anno finanziario 2018.

D.M. 15/03/2018 n.148, Decreto di riparto del Fondo per lo sviluppo degli investimenti nel cinema e nell'audiovisivo e modifiche ai decreti del Ministero dei Beni e delle Attività Culturali e del Turismo del 31 luglio 2017, emanati ai sensi degli articoli 26 e 27 della legge 14 novembre 2016, n.220.

D.M. 17/05/2018 n.245, Modifiche e integrazioni al decreto 27 luglio 2017, recante: «Criteri e modalità per l'erogazione, l'anticipazione e la liquidazione dei contributi allo spettacolo dal vivo, a valere sul Fondo unico per lo spettacolo di cui alla legge 30 aprile 1985, n. 163».

D.M. 22/05/2018 n.229, Ripartizione delle risorse aggiuntive di cui al secondo periodo del comma 87 dell'art. 145 della legge 23 dicembre 2000, n.388 in favore del Teatro dell'Opera di Roma Capitale e del Teatro alla Scala di Milano.

\section{Regional Laws}

L.R. 29/04/2004, n.6, Regolamento delle attività in materia di spettacolo ${ }^{8}$.

L.R. 06/08/2004 n.17, Norme in materia di spettacolo ${ }^{9}$.

L.R. 03/04/2009 n.11, Disciplina degli interventi regionali in materia di spettacolo ${ }^{10}$.

L.R. 15/06/2007 n.6, Disciplina degli interventi regionali di promozione dello spettacolo ${ }^{11}$.

L.R. 25/02/2010 n. 21, Testo unico delle disposizioni in materia di beni, istituti e attività culturali ${ }^{12}$.

L.R. 17/04/2015, n.16, Promozione e sviluppo dello spettacolo ${ }^{13}$.

Delibera dell'assemblea legislativa 02/02/2016 n.59, Programmazione Regionale in materia di spettacolo (L.R. 13/1999) - finalità, obiettivi, azioni prioritarie e indirizzi di attuazione per il triennio 2016-2018. ${ }^{14}$

\footnotetext{
${ }^{6}$ Fondi extra Eliseo.

${ }^{7}$ Fondi extra Santa Cecilia.

${ }^{8}$ Puglia.

${ }^{9}$ Umbria.

${ }^{10}$ Marche.

${ }^{11}$ Campania.

${ }^{12}$ Toscana.

${ }^{13}$ Basilicata.
} 
L.R. 07/10/2016, Politiche regionali in materia culturale - riordino normativo ${ }^{15}$.

L.R. 18/05/2017, n.19, Norme per la programmazione e lo sviluppo regionale dell'attività teatrale $^{16}$

L.R. 01/08/2018, n.11, Disposizioni coordinate in materia di cultura ${ }^{17}$.

${ }^{14}$ Emilia-Romagna.

${ }^{15}$ Lombardia.

${ }^{16}$ Calabria.

${ }^{17}$ Piemonte. 